\title{
ALEXANDER JOHNSTON: AN APPRECIATION
}

\author{
BY RICHARD P. MCCORMICK
}

Dr. McCormick is Professor Emeritus of History and University Historian at Rutgers University

CENTURY ago few American historians enjoyed a larger
reputation than Alexander Johnston of the Rutgers College
class of 1870 . As the Professor of Jurisprudence and Political Economy at the College of New Jersey (Princeton University) and as the author of several highly praised books and innumerable articles, he had, within the span of a decade, achieved more than most scholars could expect to accomplish over a full lifetime. In I 889 , at the age of forty, he was dead. Although his writings continued to go through successive reprintings long after his untimely death, he is now an all but forgotten figure. But his brief career was so remarkable that it merits recounting here.

Little information is available on Johnston's early years. ' He was born in Brooklyn, New York, on April 29, I 849, the son of Samuel G. Johnson and his wife, Matilda McAlan. His father served in the army during the Civil War and later moved to Illinois, leaving young Alexander and his mother in the care of an uncle, John McAloney, in Brooklyn. Johnston attended the Brooklyn Polytechnic Institute, where he was an outstanding student, and entered Rutgers College in I $866 .^{2}$

He arrived as the College was embarking on a period marked

\footnotetext{
- There is a brief biography in the Dictionary of American Biography by James A. Woodburn who, after Johnston's death, revised and kept in print some of his works. J. Hampden Daugherty, a New York lawyer and reformer, published an extended memorial address, but it is quite unreliable in many particulars and should be consulted with caution. Alexander Johnston and His Contributions to Political Science (New York, I900). There are only a few surviving papers of Johnston in the archives of Rutgers University and Princeton University.

${ }^{2}$ There is more than a little confusion associated with Johnston's name and that of his father and mother. While he was at Rutgers, and later when he was teaching at the Grammar School, he inscribed his name Johnson. By 1879 , when his History of American Politics appeared, it had become Johnston. Johnston's son reported that his grandmother's name was McAlan. But Johnston's uncle, who was presumably his mother's brother, was John McAloney. As a further complication, Johnston in his Freshman year at Rutgers gave his address as Astoria, New York, but in subsequent years it was Chillicothe, Illinois, which may have been his father's residence. See Rutgers College Catalogue, I 866-1870; Targum, Supplement, December, 1869; Biographical form, Alexander Johnston Personal File, Rutgers University Archives, Alexander Library; John McAloney to President William H. Campbell, Feb. 2, 1869, ibid. McAloney described Johnston as his ward.
} 
by unusual growth and vitality. ${ }^{3}$ Recently designated the land-grant college of New Jersey, Rutgers under the vigorous leadership of President William H. Campbell held forth exciting prospects to its students. During Johnston's undergraduate years intercollegiate sports-including football-made their appearance, the Targum was founded, a chapter of Phi Beta Kappa was established, the first students from Japan arrived, and enrollments rose from around one hundred to over one hundred fifty. In his Junior year, with the creation of the Voorhees Professorship, history was added to the curriculum.

In this lively environment, Johnston quickly distinguished himself by his obvious intellectual abilities and his zestful energy. He became a member of the Delta Kappa Epsilon fraternity and of the Philoclean Literary Society. During the Spring term of his Junior year he was editor of Targum. Of frail physique, he could not participate actively in sports, but he served as corresponding secretary of the Boating Association and was an ardent supporter of other Rutgers teams. He was among the initial group of students elected to Phi Beta Kappa. He was a participant in the customary student pranks. With the other members of his class, he was admonished by President Campbell for "sloping," i.e. "cutting," Professor David Murray's class, much to his uncle's mortification. In his Senior year he was elected Class Poet. Awarded the "first honor" by the faculty at Commencement-and named valedictorian-he also won the prestigious Brodhead Classical Prize for his proficiency in the ancient languages. 4

Following his graduation, Johnston accepted a position as a teacher in the Rutgers Grammar School, the preparatory school that was affiliated with the College. ${ }^{5}$ Soon thereafter he began to study law in the New Brunswick office of ex-Governor George C. Ludlow, and in 1875 he was admitted to the New Jersey bar. ${ }^{6} \mathrm{His}$ true vocation, however, was to be teaching. A former student de-

3 On the College in these years, see Richard P. McCormick, Rutgers: A Bicentennial History (New Brunswick, 1966), 82ff.

4 Johston's activities at Rutgers have been gleaned from the Targum, especially the issues of December, 1869, and June, October, and December, 1870. The "sloping" incident is reported in the Rutgers Faculty Minutes, Jan. 22, 23 and Feb. 22, I 869, Rutgers University Archives, and in John McAloney's letter cited in footnote 2.

5 Targum, October, 1870 .

${ }^{6}$ Ibid., November, 1875, October I 5, I889; (New Brunswick) Sunday Times, Aug. I6, 1925. 
scribed his style in the classroom. "He was a teacher of unusual force and effectiveness", Dr. William H. S. Demarest later recalled; "he was rigid, exacting, sometimes violent rather than patient; surely imperative rather than persuasive." Yet he gave his charges a thorough grounding in the classics and prepared some of the best students to enter Rutgers during his years at the Grammar School.?

Meanwhile, Johnston was also laying the foundation for his career as an historian. An omnivorous reader in the field of American history since his childhood and possessed of a tenacious memory, he abandoned a projected textbook on Greek grammar and embarked instead on his favorite subject, a history of American politics. The work was completed in 1879 and accepted for publication by Henry Holt on the advice of E. L. Godkin, the eminent editor of The Nation. ${ }^{8}$

Johnston's History of American Politics won immediate acclaim. Described as "the first really successful scholarly work of the kind," it was widely adopted as the basic American history text in many colleges and universities. It was used at the University of Wisconsin when Frederick Jackson Turner was an undergraduate there, and he employed it when he began his own teaching, as did Woodrow Wilson both at Wesleyan and Princeton. ${ }^{9}$ Within ten years it had gone through nine printings; a fourth edition, revised and enlarged by other hands, was issued as late as $1910 .^{\text {10 }}$

7 William H. S. Demarest, A History of Rutgers College, 1766-1924 (New Brunswick, I924), 434. Demarest remembered that as a Senior at the Grammar School, he had assisted Johnston in reading the proofs for the History of American Politics.

${ }^{8}$ Daugherty, Alexander Johnston, 7-8, I I, I2. Daugherty is clearly in error in placing Johnston in Norwalk while he was writing the book.

${ }^{9}$ Fulmer Mood, "The Development of F. J. Turner as an Historical Thinker," Publications of the Colonial Society of Massachusetts, XXXIV, Transactions, 1937-1942, 295, 295n; Ray A. Billington, Frederick Jackson Turner: Historian, Scholar, Teacher (New York, 1973), 28, 44; Arthur S. Link, ed., The Papers of Woodrow Wilson (47 vols., 1966-1985), VI, $43 \mathrm{I}$. "Whether as a preface to a more extended course of reading in American history or as a book of reference for the political editor or orator, we cannot commend Mr. Johnston's little book too highly," wrote one reviewer. Nation, Jan. 8, I880, 32.

10 The book, which in its original edition ran to 274 pages, was one of Holt's "Handbooks for Students and General Readers." It was reprinted in I880, I881, and I882. A second, enlarged edition was issued in I 883 and was reprinted in I $884, \mathrm{I} 886, \mathrm{I} 887, \mathrm{I} 888$, and 1889 . In 1890 a third edition, enlarged by William Milligan Sloane, appeared and was reprinted in 1892 . Sloane brought out a fourth edition in 1898 , and it was reprinted in I9OI, I902, 1907, and 1910. I have relied on The National Union Catalogue Pre-1956 Imprints in identifying the several reprintings and new editions of this and other of Johnston's publications. Sloane held the Professorship of History at Princeton while Johnston taught there. In 1896 he was lured to Columbia University. 
Johnston's American Politics gained wide approval for its distinctive qualities. It was basically a history of American political parties, whose policies and actions were traced through successive administrations beginning in I 789 . In Johnston's view, the parties represented opposing interpretations of the Constitution. "The question of a strict or a loose construction on the Constitution," he declared, "has always been at the root of legitimate national party differences in the United States." "Within this elemental framework, he proceeded Congress-by-Congress and election-by-election to sketch the course of American politics. Unlike previous texts, his completely ignored the Colonial period, eschewed anecdotes, diminished the role of personalities, avoided literary embellishments, and sought to maintain a posture of utter objectivity. Here was a sparse narrative designed to present the basic "facts" of American political history. Within its obvious limits, it was remarkable for the accuracy of its statements and for the comprehensiveness of its coverage.

Soon after the book appeared, Johnston left New Brunswick to become the principal of a Latin School in Norwalk, Connecticut. ${ }^{12}$ Almost immediately he became engaged in another scholarly enterprise. John J. Lalor, who had translated Herman Von Holst's Constitutional History of the United States, conceived the idea of publishing an American encyclopedia of political science and history on the model of those which had been produced in France, Germany, and Italy. Johnston accepted his invitation to write all the articles on American political history for this ambitious project. ${ }^{13}$ It was a formidable assignment, but he completed the task by I 883 , and the last of the three bulky volumes of the Cyclopaedia of Political Science, Political Economy, and of the Political History of the United States appeared a year later. ${ }^{14}$ Johnston's contributions amounted to

"Johnston, American Politics, 2.

¿2 Woodburn, "Alexander Johnston."

${ }_{13}$ Alexander Johnston to Prof. I. E. Hasbrouck, Norwalk, Dec. I 5, I 880 . Alexander Johnston Personal File, Rutgers University Archives. In this letter, Johnston reported that he had been asked to translate the third volume of Von Holst's Constitutional History but that he would probably decline because of other obligations.

${ }^{14}$ The first volume published by Rand, McNally in Chicago appeared in I $88 \mathrm{I}$. Volume two was published in $\mathrm{I} 883$ and the third volume a year later. The publisher of the latter two volumes was Melbert B. Cary of Chicago. "The task of writing the articles on the political history of the United States was confided to one person, Mr. Alexander Johnston ...., thoroughness, conciseness, and the absence of repetition and redundancy being thus secured," Lalor explained in the Preface. 
the equivalent of one thousand octavo pages. In addition to political histories of every state and every political party, he provided accounts of every major incident in American history as well as brief biographies of leading statesmen. Appended to each article was a substantial bibliography. The work as a whole was well received, but the highest encomiums were awarded to Johnston for his prodigious achievement. ${ }^{5}$ If his American Politics had launched his reputation as an historian, his great work on the Cyclopaedia secured it.

As an immediate consequence of this latest accomplishment, he was appointed to the chair of Jurisprudence and Political Economy at Princeton. Unfortunately, the duties of the chair did not include the teaching of history. Because of his legal studies, Johnston had an adequate background in jurisprudence, but now he had to master the field of political economy, a feat that he accomplished by reading voraciously on the subject. During his tenure at Princeton, he taught courses in Political Economy, Philosophy of Public Law, International Law, American Constitutional Law, English Common Law, and Roman Law. In his fourth year of teaching, with the cordial acquiescence of the Professor of History, he ventured to give a one-semester course in the Political History of the United States, using his American Politics as the required text. ${ }^{16}$

Johnston quickly assumed an important role in the Princeton faculty as one of the leaders of the progressive faction. He worked effectively to add new subjects to the curriculum and to permit greater latitude in the choice of elective courses. As one colleague who was usually to be found on the conservative side characterized him, he was 'a 'prime mover' rather than an 'anchor'; quick to see the changes that new times are always calling for, and urgent in their advocacy." He was popular with his students because of his stimulating teaching and also because of his keen interest in Princeton sports. An enthusiastic and extremely knowledgeable football

is In 1905 James A. Woodburn arranged and edited Johnston's Cyclopaedia articles to produce a reasonably coherent narrative. It was published by Putnam's in two volumes totalling nearly one thousand pages under the title American Political History, ${ }_{17} 63^{-1} 876$. The volumes were reprinted in I912-1913.

${ }^{16}$ The Professor of History was William Milligan Sloane, whose field was European history. For Johnston's courses year by year, see the Catalogue of the College of New Jersey, I $883-1884$ to I $888-1889$. There are printed syllabi for courses he offered in Jurisprudence and in Political Economy, but not for American history, in Johnston's thin personal file in the Princeton University Archives housed in the Seeley C. Mudd Manuscript Library. 
fan, he not only attended all the games but made it a point to observe the pre-season practice sessions as well. ${ }^{17}$

Despite his heavy instructional burden, Johnston somehow maintained his awesome literary output. In I 884 G. P. Putnam's Sons published in three volumes his Representative American Orations. The work included selected speeches of leading political figures on the major issues of their times and was intended to illustrate the course of American politics from the Revolutionary era through Reconstruction. For each of the eight periods into which he divided the subject, Johnston wrote introductory essays that provided a useful background for the orations. Ponderous though such a publication might seem, it went through ten printings down to $1927 .{ }^{18}$

A year later, he published his History of the United States for $S$ chools. Intended for students on the secondary level, this substantial text was an immediate commercial success. By 1895 it had been reprinted nine times, and subsequently revised editions were brought out by Winthrop More Daniels and William MacDonald as late as $1907 .{ }^{19}$ At the insistent urging of Henry Holt, Johnston prepared a briefer version of this text which appeared in I 890 as A Shorter History of the United States for Schools. Evidently it did not garner a large share of the market, for it had only three printings to $\mathrm{I} 897 .{ }^{20}$

17 Johnston's role in the faculty is described by his colleague, Prof. C. A. Young in The Critic, Aug. 3, 1 889, 56. His zest for, and expert knowledge of, football is evident in his charming article, "The American Game of Football," Century Magazine, XXXIV (Oct., I 887), 888-98.

${ }_{18}$ The full title was Representative American Orations to Illustrate American Political History. The work was reprinted in 1886, I 887, I 888 , and 1890 . After Johnston's death, a fourvolume edition, "re-edited with historical and textual notes" by James A. Woodburn, was brought out in I 896-I 897 by G. P. Putnam's Sons with the title, American Eloquence. In the same year, the volumes also appeared as American Orations, Studies in American Political History, and under that rubric they were reprinted in I899-I903, I90I-I904, I 908 , and 1927 , on the last occasion with an introduction by George Haven Putnam.

${ }_{19}$ This text, which ran to 473 pages and included maps, plans, and illustrations, was published by Henry Holt. It was reprinted annually down to I895, except for I 893. In I 897 Daniels prepared a revised edition, and yet another revision was done by Daniels and MacDonald, which appeared in 1902 and I906. Essentially the same work was published in I 901 and 1907 under the title, High School History of the United States.

${ }^{20}$ Four letters to Henry Holt between February i 8 and March I7, I886, reveal the pressure Johnston was under as he sought to complete the Shorter History while he was struggling to meet other commitments. He carefully examined the two competing textbooks in the field in an effort to make his superior. By this time Johnston had adopted the latest technology; his letters were typed. Henry Holt Papers, Box 6r, Folder I, Princeton University Library. The Shorter History, 340 pages in length, was reprinted in I 897 . Evidently George P. Butler of the Lawrenceville School assisted in preparing the manuscript for publication after Johnston's death. The Critic, Mar. 7, I891, I 23. 
Along with his work on these textbooks, Johnston was bringing to completion a far more taxing project. In April, i 883, he had travelled to Baltimore to read a paper on "The Genesis of a New England State" before the Historical and Political Science Association at the Johns Hopkins University. ${ }^{21} \mathrm{He}$ traced the origins and early histories of the Connecticut and New Haven colonies down to their merger in I664, emphasizing the theme that each colony was in reality based on a federation of democratically run towns. This concept was elaborated in his Connecticut: A Study of a Commonwealth Democracy, published as volume ten of the American Commonwealths series by Houghton, Mifflin Company in I 887. Johnston argued that Connecticut merited recognition for having first developed the principles of democracy and federalism in America. By its example, and through the contributions of its delegates to the Constitutional Convention, it was influential in shaping American governments generally in accordance with those principles. An ultra-Jeffersonian in his belief in minimal government and personal freedom, Johnston hailed the Connecticut system for the encouragement it gave to "individual energy and capacity." Of the book's twenty chapters, only two dealt with the years after I 789 , but the treatment of the colonial period was comprehensive and-despite an overstated thesis-by far the best survey of the subject then available. ${ }^{22}$

By this time Johnston's writings had become well known in England, as well as in America, and they attracted the attention and admiration of James Bryce, who was then bringing to completion his splendid volumes on The American Commonwealth. On Bryce's recommendation, Johnston was invited to contribute a lengthy essay on the history of the United States to the ninth edition of the Encyclopaedia Britannica. ${ }^{23}$ In 1889 Charles Scribner's Sons reprinted the piece with the title The United States, Its History and

\footnotetext{
${ }^{21}$ Johns Hopkins University Studies in Historical and Political Science, I, no. I I (Baltimore, I 883 ).

${ }_{22}$ This work was reprinted in I890, I89I, I 893, I 895, I 896, I898, I 900 , I 903 , and I 9 I 5. A reviewer praised its "easy and graceful style" but was critical of Johnston's extreme claims for the influence of Connecticut on the American system of government. Nation, July 7, I887, I 5-16. See also The Critic, July 23, I 887,38 .

${ }_{23}$ Daugherty, Alexander Johnston, 28. Daugherty stated that this article was written between February and May 1887 . The Encyclopaedia Britannica (9th ed., 25 vols, New York, I 87889). Johnston also contributed biographies of George Washington and Daniel Webster.
} 
Constitution. In many respects, this was the best of Johnston's books. He summarized the whole sweep of American history from the colonial foundations through Reconstruction in eleven well-organized, tightly-written chapters. Although he gave priority to the political narrative, he was attentive to important social, economic, and cultural developments, treated westward expansion and the attendant rise of sectionalism, and even took cognizance of immigration as a significant factor in shaping the nation. It was a superb work of synthesis and a demonstration of Johnston's extraordinary mastery of the literature of American history. ${ }^{24}$

The enormous intellectual effort represented by these several volumes did not entirely exhaust Johnston's scholarly energy. He wrote a section on "The History of Political Parties, I 789 -I 850 " for the seventh volume of Justin Winsor's Narrative and Critical History of America. ${ }^{25} \mathrm{He}$ was a frequent contributor of essays to The Nation, Century Magazine, The New Princeton Review, and The Citizen. Especially notable was a piece on "The First Century of the Constitution," in which he boldly challenged Gladstone's oftquoted statement that the American Constitution was "the noblest work ever struck off by the brain and purpose of man." ${ }_{26}$ The great document, he argued, was not created by inspired men; rather, its enduring quality derived from the shrewdness of the Framers in adapting institutions and procedures that had long been tested in the colonial and state governments. "The best reason for American pride in the Constitution," he concluded, "lies in the fact that it was and is a perfect expression of the institutional methods of its people." So impressed was James Bryce by this analysis that he included much of the article in an appendix to the first volume of his American Commonwealth. ${ }^{27}$

His unremitting labors undermined Johnston's health. Shortly before his death he reported uncomplainingly: "My illness has been

${ }^{24}$ The book, with bibliography, appendix, and index, totaled 286 pages. It was published in London by Blackie in I 890 and was reprinted by Scribner's in I891, I 892, I896, I 900 , I902, and I 905 .

${ }_{25}$ The volume was published in 1888 by Houghton, Mifflin. Johnston's contribution is Chapter V, 267-93.

${ }_{26}$ New Princeton Review, September, I887, 175-90.

${ }^{27}$ James Bryce, The American Commonwealth (2 vols., New York and London, I 889), 1, 666-69. 
almost continuous since July, 1887 . . . It was over work, break down and nervous collapse." 28 After a brief period of recovery in I 888 , he was again stricken that summer and had to undergo an operation. During his final year at Princeton he was often confined to his bed and was unable to meet his classes. ${ }^{29}$ On July 20, I $889-$ less than three months after his fortieth birthday-he died; the diagnosis was heart disease. His survivors included his widow, Mary Louise Carter, whom he had married on August 29, I 878 , in Norwalk, a son, and three daughters. At his funeral, the eulogy was delivered by President Francis Patton of Princeton who extolled his human qualities as well as his scholarly achievements. The benediction was pronounced by Professor Jacob Cooper, who had taught him at Rutgers, and among the pallbearers was Austin Scott, the Voorhees Professor of History at Rutgers. $3^{\circ}$

Johnston is best characterized as a highly skilled craftsman rather than as a brilliant thinker or innovative scholar. His special talent lay not in original research but in a mastery of the available literature of American history, combined with the ability to write clear prose with remarkable facility. One of his special resources was an immense personal library of some three thousand volumes that was thoughtfully selected to further his historical writings as well as his teaching of jurisprudence and political economy. ${ }^{31}$ It is obvious from his record of productivity that he was possessed as well of amazing intellectual energy.

He represented, in a sense, a transitional stage in the evolution of American historiography. When he launched his career in I 879 , historical writing was still the preserve of the amateur; only a handful of scholars had been trained in American graduate schools.

${ }^{28}$ Johnston to D. O. Kellogg, Mar. 28, 1889, in The Critic, Aug. 10, 1889, 68. His last public appearance was at the Fellowcraft Club in New York, of which he was a loyal member, in the Spring of I 889 . "He spoke on that occasion ably but not without effort." Ibid., Aug. 3, I889, 48 .

${ }^{29}$ Johnston to Moses Taylor Pyne, Sept. 26, I 888, Alexander Johnston Personal File, Princeton University Archives. His teaching duties were assumed by Professor Austin Scott of Rutgers College and by President Patton.

30 There is an elaborate account of the funeral, including Patton's address, in the Princeton Press, July 27, I 889. There were other obituaries in the Targum, Oct. I 5, I889; The Critic, Aug. 3, I 889, 56; Century Magazine, XXXVIII (Oct., I 889), 948; Nation, July 25, I 889, 72-73; Princeton College Bulletin, Nov., I 889; and New York Times, July 22, 1889. The information on his family, supplied by his son, Alexander Johnston, is in Alexander Johnston Personal File, Rutgers University Archives. Johnston's successor at Princeton was Woodrow Wilson.

${ }_{31}$ Catalogue of the Library of the Late Professor Alexander Johnston . . to be Sold at Auction Jan. $14,{ }_{15},{ }_{1} 6,{ }_{1} 890$, Bangs $\mathcal{E}^{2}$ Co., N.Y.C. (n.p., I890). 
There was, strictly speaking, as yet no historical profession; there were no more than a score of full-time teachers of history in American colleges and universities. Writers of history wrote not for a scholarly audience, as is the case today, but for the literate public, for the earnest citizen, and for the schools. So it was with Johnston, and he excelled in his craft. Long after his death, one of the most esteemed and popular historians of his day, John Fiske, commented on Johnston's work:

The most useful handbook, alike for teachers and pupils, is Alexander Johnston's History of American Politics. . . . The United States; its History and Constitution] . . . by the same author is also excellent. Every school should possess a copy of Lalor's Cyclopaedia. $\therefore$ The numerous articles in it relating to American history are chiefly by Alexander Johnston, whose mastery of his subject was simply unrivalled. ${ }^{32}$

Although he was representative of the older, amateur tradition, Johnston also bridged the transition to the new professionalism. He was one of the forty men who met at Saratoga, New York, in September, I 884 , to found the American Historical Association, and he was regular in his attendance at the annual meetings. ${ }^{33} \mathrm{His}$ professorship at Princeton brought him formally into the academy and further insured his acceptance by his professional colleagues. What his course might have been had his life been prolonged to a normal span must remain conjectural, but it is not unreasonable to assume that he would have become involved in the training of graduate students and in pursuing in-depth his study of the development of American political parties.

One of the features of Johnston's historical style most admired by his contemporaries was his high degree of objectivity, yet he was not entirely free of interpretive bias. He was, to use John Higham's term, a conservative evolutionist. ${ }^{34}$ That is, he had great regard for long-established institutions, which he believed should be permitted to evolve in a "natural" manner without being subjected to abrupt, unsettling changes. But he was prepared to argue that a blind, logical adherence to outmoded laws could be impolitic, even suicidal. ${ }^{5} \mathrm{He}$ even proposed that a second Constitutional Convention should be called to rectify some of the procedural in-

${ }^{32}$ Civil Government in the United States (new ed., Boston and New York, 1904), 289.

${ }_{33}$ Papers of the American Historical Association, I (New York, 1885), 22.

${ }_{34}$ John Higham, History (Englewood Cliffs, N.J., I965), I 50 off.

${ }_{35}$ "Law, Logic, and Government," New Princeton Review, March, I 888, I87-200. 
adequacies of the Federal Constitution. ${ }^{36} \mathrm{He}$ was scornful of the doctrine of state sovereignty, but he extolled the importance of state rights within our federated system of government. In general, he was a believer in the policy of laissez faire, in individualism, and in responsible democracy. As for political parties, he admired them when they actively represented great principles and deplored them when they functioned as self-serving agencies of grubby politicians. ${ }^{37}$

Alexander Johnston, then, ranked near the summit of his profession when his life ended at the age of forty. His passing was widely mourned, and many were the tributes to his accomplishments, along with fulsome expressions of regret that his fertile mind and pen would produce no more. ${ }^{38}$ Rutgers had recognized his achievements in his lifetime by conferring on him in 1886 the honorary degree of Doctor of Laws. ${ }^{39}$ Much later it named the building that had once housed the Rutgers Grammar School in his memory-Alexander Johnston Hall. $4^{\circ}$ And this brief appreciation signifies that he is still held in kindly remembrance at his alma mater.

${ }_{36}$ "Shall We Have a Second Federal Convention?" Princeton Review, May, I 884, 30418. He recommended that the Second Convention should end the power of Congress to canvass the electoral vote, restrict special legislation, forbid the attachment of "riders" to bills, give the President an item veto, provide constitutional status for Civil Service, and vest in Congress exclusive jurisdiction over marriage and divorce laws.

${ }^{37}$ Johnston's views on contemporary issues were voiced frequently in the "Topics of the Times" section of Century Magazine. In a tribute to him the editor wrote: "He valued above all else the old-fashioned idea of personal freedom with its corollary of personal initiative and responsibility, emphasized at all times the essential character of local rights and government, and the subservience of political theory to historical induction." Ibid., XXXVIII (October, I 889), 948. He wrote anonymously, True or False Finance, the Issue of 1888 (New York, I 888), a political tract inspired by the presidential election that year.

${ }^{38}$ See footnote 30.

39 Johnston to David D. Demarest, June 26, I 886, Alexander Johnston Personal File, Rutgers University Archives.

${ }^{4}$ The building, at the northwest corner of College Avenue and Somerset Street, was erected in 1830 to house the Grammar School and the two literary societies of the college. It was greatly enlarged forty years later. Demarest, Rutgers College, 308-309. 